\title{
Laser-scanner used in a wind tunnel to quantify soil erosion**
}

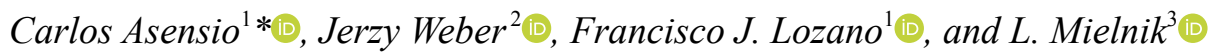 \\ ${ }^{1}$ Department of Agronomy, University of Almeria, Campus de Excelencia Internacional en Agroalimentacion, Ctra. Sacramento s/n, \\ 04-120 Almeria, Spain \\ ${ }^{2}$ Institute of Soil Science and Environmental Protection, Wrocław University of Environmental and Life Sciences, Grunwaldzka 53, \\ 50-357 Wrocław, Poland \\ ${ }^{3}$ Department of Physics and Agrophysics, West Pomeranian University of Technology in Szczecin, 3 Papieża Pawła VI St, \\ 71-459 Szczecin, Poland
}

Received August 23, 2018; accepted November 14, 2018

\begin{abstract}
A methodology was developed in order to estimate wind erosion by comparing the differences in soil loss with a 3D laser scanner inside a wind tunnel, to relate the change in soil micro-relief to soil loss. We evaluated the effectiveness of a low-cost laser scanner in a wind tunnel for examining the winddependent variation in soil surface micro-topography, thereby enabling soil wind erosion to be quantified both quickly and accurately. We, therefore, studied the effect of soil crusting in an intensive horticultural crop, low-tilled soil (once a year) in cereal cultivation, and tilled soil (several times a year) in an ecological citrus orchard, paying attention to the changes occurring when soils are tilled. Moreover, we observed an aggregation effect of $\mathrm{CaCO}_{3}$ in the wind-erodible fraction, a protective effect of surface stoniness against a direct impact of wind and the incidence of soil particle content. Different behaviour, in terms of random roughness, is due to more stones and/or remnant vegetation being highly resistant to wind in Calcisol, Cambisol, Fluvisol and Arenosol plots, thus increasing surface roughness. In Anthrosol and Leptosol plots, on the contrary, initial roughness was due to large unstable and wind-eroded aggregates which resulted in a decreased surface roughness. loss

Keyw ords: soil roughness, tilled soils, wind erosion, soil
\end{abstract}

\section{INTRODUCTION}

Soil erosion is currently a major cause of both European and global land degradation (Borrelli et al., 2016). Therefore, more studies are needed to improve the current models, and plot and regional studies must be integrated to facilitate decision-making. Soil degradation is related to soil com-

\footnotetext{
*Corresponding author e-mail: casensio@ual.es

**This work was funded by the Andalusia Regional Government (RNM 3614 grant, 2009-2013 and RNM 5887 grant, 2011-2015) and European Union ERDF funds (2011-2015).
}

paction, the loss of vegetation and organic matter, and an increased soil erosion by both wind and water (Novara et al., 2011). Wind erosion is a worldwide environmental concern which affects some regions of the world more than others because of their climate conditions (Borrelli et al., 2016; Weber et al., 2017). The Mediterranean climate, along with a low soil organic matter content, a poor soil structure and a weak stability of aggregates, cause frequent soil crusting. Le Bissonnais et al. (2002), based on the 1:1000000 European soil database, estimated that in Spain $70 \%$ of soils are susceptible to crusting, and that southeast Spain appears to be an especially susceptible area. Although crusts constitute an insignificant portion of the soil profile (a few millimetres thick), their role in the ecosystems is quite significant, because they constitute the boundary between soil and air. Crusts control water, gas and heat flows between soils and the atmosphere, acting on the under-surface nutrient flows and soil conditions, thereby making their influence on plant development decisive (Belnap, 2003).

Benlhabib et al. (2014) analysed dryland Mediterranean cultivation systems, discussing and recommending sustainable cultivation technologies which showed a significantly positive effect on crop productivity, yield stability and environmental sustainability. Zobeck et al. (2013), and Colazo and Buschiazzo $(2010,2015)$ confirmed that cultivation increased the erodible fraction of soil (EF) and reduced dry aggregate stability (DAS) in medium-textured soils by

(C) 2019 Institute of Agrophysics, Polish Academy of Sciences 
weakening the soil structure due to the loss of organic carbon (OC) and breakup of aggregates. In fine-textured soils, the formation of large resistant clods by tilling was found to cause EF and DAS to be more alike than under no-till conditions. According to Rawlins et al. (2015), soils with more stable aggregates have larger disaggregation reduction values. Hagen et al. (2010) observed that tilling ridges are effective for trapping the aggregates transported by saltation, but do not usually reduce erosion rates in the soils where aggregates transported by suspension predominate.

Vegetation can diminish the soil loss from wind because it reduces wind speed and soil erodibility, trapping more eroded material (Leenders et al., 2011; Lozano et al., 2013). In their wind tunnel experiments, Udo and Takewaka (2007) arrived at the conclusion that, in addition to density, plant height and flexibility are essential in determining its effectiveness in lowering mass transport by wind. Youssef et al. (2012) suggested that the vegetation grown in rows parallel to the predominant wind direction lowers total material transport.

A very precise measurement of three-dimensional points located on the soil surface is required to detect changes in the surface micro-topography of crusted soils. This is easier in tilled soils. As material loss in crusted soils can involve variations in height of much less than $0.5 \mathrm{~mm}$, several different methods have been used to characterize soil micro-relief, for which measurement by a laser scanner is one of the best alternatives, due to its accuracy (Asensio et al., 2016).

In view of the above, our objectives were to: (1) develop a methodology based on soil micro-relief measurements with a 3D laser scanner inside a wind tunnel, to relate the change in soil micro-relief to soil loss, in order to estimate wind erosion; (2) compare the differences in soil loss by soil type; and (3) observe changes in the amount of dust created when soils are tilled.

\section{MATERIAL AND METHODS}

The study took place in the Campo de Nijar district (36 $48-59^{\prime} \mathrm{N}, 2^{\circ} 3-29^{\prime} \mathrm{W}, 5-340 \mathrm{~m}$ a.s.l.), Almeria Province, in Southeast Spain, between the Sierra de Alhamilla Mountains and the Mediterranean Sea. The semiarid thermoMediterranean climate, with a mean annual temperature of $17.9^{\circ} \mathrm{C}$ and a 15 -year mean annual precipitation of $247 \mathrm{~mm}$, according to the Nijar meteorological station records, is one of the driest areas in Europe. The lithological material is predominantly formed by a metamorphic basement in the Alpujárride and Nevado-Filábride complexes, separated by Neogene and Quaternary sedimentation basins. Natural plant communities are composed of isolated native shrubs surrounded by areas of bare soil colonized by biological crusts and annual plant species (Cantón et al., 2011). Soils are mainly Arenosols (AR), Anthrosols (AT), Calcisols (CL) Cambisols (CM), Fluvisols (FL) and Leptosols (LP).
Texture ranges from silty clay loam to loamy, with variable gravel fragments, and a weak and coarse subangular blocky to medium angular blocky structure.

The parameters of different soil types, such as gravel, texture, organic carbon and equivalent carbonate content, were analyzed before generating forced wind, in order to acquire baseline data. Soil samples were taken from the upper $3 \mathrm{~cm}$ layer of both crusted and recently tilled agricultural soils. To determine bulk density (BD), $100 \mathrm{~cm}^{3}$ cylinders were used to refer to sample dry weight by cylinder volume. The analyzed soils baseline data show that the surface stoniness of these soils is variable (very low in AT and especially high in LP), and the average gravel for the different typologies varies from $5 \pm 4 \%$ in AT to $42 \pm 8 \%$ in $\mathrm{CM}$, as shown in Table 1. Texture presents differences for an average very fine sand plus coarse silt from $3.4 \%$ in AR to $48.5 \%$ in $\mathrm{CM}$ (Table 2). Organic carbon content was found to fluctuate from $0.90 \pm 0.08 \%$ in CL to $2.54 \pm 0.18 \%$ in LP, and equivalent carbonate content from $40+6 \%$ in CL to $1 \pm 1 \%$ in $\mathrm{AR}$.

Table 1. Gravel, organic carbon (O.C.) and equivalent carbonate $\left(\mathrm{CO}_{3}{ }^{\circ}\right)$ content in soils $(\mathrm{n}=5)$

\begin{tabular}{cccc}
\hline \multirow{2}{*}{ Sample } & Gravel & O.C. & $\mathrm{CO}_{3}{ }^{=}$ \\
\cline { 2 - 4 } & \multicolumn{3}{c}{$(\%)$} \\
\hline AR & $7 \pm 2$ & $1.28 \pm 0.08$ & $1 \pm 1$ \\
AT & $5 \pm 4$ & $1.72 \pm 0.14$ & $22 \pm 4$ \\
CL & $24 \pm 5$ & $0.93 \pm 0.08$ & $42 \pm 6$ \\
CM & $42 \pm 8$ & $2.54 \pm 0.78$ & $21 \pm 3$ \\
FL & $32 \pm 6$ & $2.14 \pm 0.82$ & $22 \pm 4$ \\
LP & $35 \pm 6$ & $2.51 \pm 0.17$ & $17 \pm 3$ \\
\hline
\end{tabular}

Data are means \pm standard deviation.

To analyze the soil volume loss and its effect on surface micro-topography, both crusted and recently tilled soils data were included. Despite the low rainfall in the area, humidity is high and dew has an important role in the physical crusting of soils. Crusted soils are strongly protected from wind erosion, while right after tilling they are highly susceptible to it. The frequency of soils tillage determines the existence of remnant vegetation with a protective effect against wind, and a greater or lesser tendency towards the rapid formation of physical crusts. For our tests, the tilling of all soil types was done manually and in the same manner, following which the soils tended to recover their physical surface crust within 8 to 10 days, reacquiring protection against wind (Cantón et al., 2009).

Simulations were done in April 2015 for five plots per soil type. Sometimes aisles between the rows were very close to the predominant wind direction (there was about a $10^{\circ}$ offset in FL). Field slope and length in the five tilled experimental plots measured show an average of $0 \%$ and $300 \mathrm{~m}$ on $\mathrm{AT}, 2 \%$ and $180 \mathrm{~m}$ on CM, and $1 \%$ and $150 \mathrm{~m}$ on 
Table 2. Textural components in soils $(n=5)$

\begin{tabular}{|c|c|c|c|c|c|c|c|c|}
\hline \multirow{4}{*}{ Sample } & \multicolumn{5}{|c|}{ Sand } & \multicolumn{2}{|c|}{ Silt } & \multirow{3}{*}{$\begin{array}{c}\text { Clay } \\
<2\end{array}$} \\
\hline & & & & \multicolumn{2}{|c|}{$(\%)$} & & & \\
\hline & $\begin{array}{c}2000- \\
1000\end{array}$ & $\begin{array}{c}1000- \\
500\end{array}$ & $\begin{array}{l}500- \\
250\end{array}$ & $\begin{array}{c}250- \\
100\end{array}$ & $\begin{array}{c}100- \\
50\end{array}$ & $\begin{array}{l}50- \\
20\end{array}$ & $\begin{array}{c}20- \\
2\end{array}$ & \\
\hline & \multicolumn{8}{|c|}{$\mu \mathrm{m}$} \\
\hline $\mathrm{AR}$ & $0.4 \pm 0.1$ & $6.1 \pm 0.5$ & $48.7 \pm 6.4$ & $38.4 \pm 3.7$ & $2.7 \pm 0.3$ & $0.4 \pm 0.2$ & $0.2 \pm 0.1$ & $3.1 \pm 0.2$ \\
\hline AT & $5.5 \pm 0.3$ & $11.3 \pm 0.5$ & $22.7 \pm 1.6$ & $31.0 \pm 2.6$ & $20.1 \pm 1.6$ & $0.5 \pm 0.2$ & $2.3 \pm 0.3$ & $6.6 \pm 0.6$ \\
\hline $\mathrm{CL}$ & $6.2 \pm 0.6$ & $6.0 \pm 0.4$ & $9.4 \pm 0.9$ & $19.5 \pm 1.7$ & $22.3 \pm 2.1$ & $7.6 \pm 0.5$ & $11.6 \pm 0.9$ & $17.4 \pm 1.2$ \\
\hline $\mathrm{CM}$ & $0.1 \pm 0.1$ & $8.2 \pm 1.2$ & $7.5 \pm 1.0$ & $8.7 \pm 0.8$ & $20.2 \pm 3.1$ & $28.3 \pm 3.2$ & $8.1 \pm 1.6$ & $18.9 \pm 1.8$ \\
\hline FL & $2.1 \pm 0.2$ & $5.2 \pm 0.3$ & $7.0 \pm 0.4$ & $8.7 \pm 0.3$ & $15.5 \pm 0.8$ & $22.0 \pm 1.4$ & $18.3 \pm 0.5$ & $21.2 \pm 1.1$ \\
\hline LP & $15.3 \pm 1.2$ & $14.8 \pm 0.8$ & $22.3 \pm 2.3$ & $24.8 \pm 2.1$ & $5.2 \pm 0.4$ & $6.3 \pm 0.3$ & $2.5 \pm 0.3$ & $8.8 \pm 0.5$ \\
\hline
\end{tabular}

Explanations as in Table 1.

FL. Slopes and lengths in the non-tilled soil plots were $1 \%$ and $75 \mathrm{~m}$ on AR, $0 \%$ and $200 \mathrm{~m}$ on CL, and $3 \%$ and $100 \mathrm{~m}$ on $L P$, respectively.

The acquired data on soil characteristics were examined to identify any changes or differences. Any further analyses were preceded by checking the normal distribution of data and the homogeneity of variances, using the Shapiro-Wilk and Levene's tests, respectively. Pairwise comparisons were assessed using the least significant difference test. All statistical analyses were carried out with SPSS v20 (IBM Corp., 2011).

To monitor wind intensity, as well as direction and shear intensity, we worked with a portable wind tunnel with a laminar and turbulent flow similar to real wind conditions, due to an industrial fan which blows air through a honeycomb structure. The transported material was collected in traps for the study (Fig. 1). The tunnel itself consisted of three telescoping compartments $(0.8 \times 0.8 \times 0.8 \mathrm{~m}$ each $)$. The first compartment had a metal sheet completely covering the ground so the wind would not affect it. The second compartment was the study area, where wind erosion was actually quantified. This compartment was equipped with a PCE-424 hot wire anemometer with $0.1 \mathrm{~m} \mathrm{~s}^{-1}$ resolution for monitoring wind speed. A NextEngine Desktop 3D laser scanner was used to determine the volume of eroded soils and the alterations in soil micro-relief. This low-cost device (around $3000 €$ ) was attached to a lift support system, which enabled its setting at a desired height or removal. In the third compartment, a liquid latex (Latepren ${ }^{\circledR} \mathrm{Rx}-505$ ) coating was applied to the soil surface to fix the particles so they did not move around during blowing and became mixed with the particles in the study zone. This ensured the natural roughness of the ground. The latex coating was spread in a bulb shape from outside the third tunnel compartment to avoid the return of particles from outside with edge turbulence. The particles were finally caught by traps at the end of the tunnel (Asensio et al., 2016).

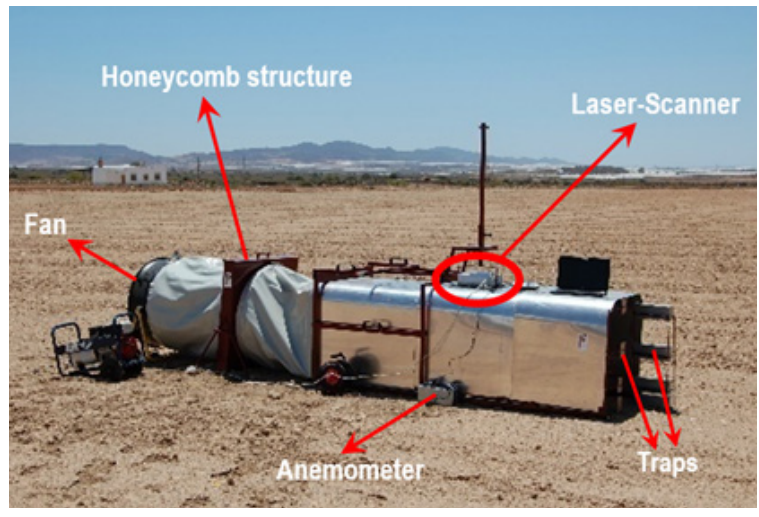

Fig. 1. Wind tunnel located on a crusted Anthrosol.

The wind tunnel experiment lasted $10 \mathrm{~min}$ at a wind speed of $6.8 \mathrm{~m} \mathrm{~s}^{-1}$ and a height of $70 \mathrm{~cm}$, following the criteria proposed by Fister and Ries (2009). This wind speed corresponded to the 15-year maximum daily average recorded at the Nijar Meteorological Station, which is part of the Andalusian Regional Government automatic network.

In each experiment, the ground was scanned twice, before and after wind simulation. Scans were done at a height of $44 \mathrm{~cm}$, using a laser scanner under naturally dry conditions. The laser lift system enabled the device to be set at a fixed height. The scanner had already proven useful in acquiring the micro-reliefs of agricultural soils (Aguilar et al., 2009) in high-precision field work (High Definition mode and MACRO) with a sample size large enough to represent the plot in great detail. It was capable of providing a $120 \mathrm{~cm}^{2}$ scan area with a 400 ppi capture density and a nominal precision of $0.127 \mathrm{~mm}$. Two $0.1 \times 0.1 \mathrm{~cm}$ resolution digital terrain models (DTMs) were generated, based on two-point clouds for each plot (before and after wind simulation). Soil loss was estimated as the difference in volume between the two DTMs, taking bulk density into account. Five scans of each of the five soil plots were averaged so that the measurements could be considered representative. 
After analyzing the soil volume lost due to wind erosion, we studied its effect on the surface micro-topography, from both crusted and recently tilled soil. Windward material deposits would have to be considered along with the loss model for the erosion balance to be more accurate, but this was not possible inside a wind tunnel. However, comparisons could still be made with this system.

To find out how wind erosion modifies surface microtopography, a point cloud from each scan was used to calculate random roughness (RR), both before and after simulation. RR is defined as the standard deviation from points within the plot after eliminating the slope effect. But in natural areas with a complex topography or with wide variation (changes in both flat curvature and profile), eliminating the slope does not cancel out the effects on changes in height caused by roughness factors, such as mounds, curvature or higher-order variations in surface, so the RR index tends to overestimate surface roughness in experimental plots. Therefore, the local RR index $\left(R R_{L}\right)$ estimation method was applied (Rodríguez-Caballero et al., 2012) using equation:

$$
R R_{L}=\sqrt{\sum_{i=1}^{i=N w(Z w-\mu w)^{2}}}
$$

where: $N w$ is the number of points in Window $w, Z w$ is the height of each point, after eliminating the slope effect, and $\mu w$ is the mean height in Window $w$.

\section{RESULTS AND DISCUSSION}

When the average bulk density of each soil type had been obtained, losses and deposits in an area with a size of the micro-plot which the laser scanner could detect were examined. The results for the six soil types in the particles blown with the same wind intensity, generated artificially by the tunnel, are shown in Table 3. This table shows the differences in the material losses detected by the laser scanner in crusted soils and in newly tilled soils, as well as the resulting wind erosion detected. Once the height differences and soil average bulk density values were known to us, we could establish the wind erosion balance. The balance included the wind erosion mass collected in wind tunnel traps. In fact, the values of wind erosion obtained by the traps were significantly lower, which could be attributed to the different global areas of the study for both methods. With the laser scanner, we analysed what happened in a micro-plot, while the traps collected material from 0.64 $\mathrm{m}^{2}$, although part of the wind-detached material was deposited on the soil surface before reaching the traps (the more so, the greater roughness). Despite the differences in the methods of assessing the wind-eroded soil mass, the correlation coefficient of the soil losses detected by the laser to the amount of the material collected by the traps located at the end of the tunnel was 0.893 for the six soil types tested, which can give us some idea about the suitability of this method.

Taking into account both the type of land use/crop and soil properties, in comparing the average soil loss in crusted and tilled soils, tilling increased the loss of AT under intensive horticultural crops about twice as much as in crusted soils, over three times CM under the cereal, and over four times FL under ecological citrus crops. This result only considers a loss model and does not consider deposition of material brought by wind.

As suggested by Lozano et al. (2013) and Asensio et al. (2015), wind erosion affects bulk density in two ways. It tends to be reduced by organic enrichment but, on the other hand, it gets increased by the accumulation of fine materials. This greatly influences physical soil crusting. Organic matter often combines with fine soil particles, and Zhao et al. (2009) found a correlation coefficient between clay and the organic matter content of 0.95 .

The digital terrain models and an erosion map for a sample collected from one AT plot are shown in Fig. 2 as exemplary scanning results. Soil loss was estimated as the difference in volume between the two DTMs (before and after wind simulation), taking bulk density into account. In this case, an average height loss of $0.51 \mathrm{~mm}\left(0.51 \mathrm{~mm}^{3}\right.$ $\mathrm{mm}^{-2}=5.1 \mathrm{~m}^{3} \mathrm{ha}^{-1}$ ) and bulk density of $1.28 \mathrm{t} \mathrm{m}^{-3}$ implicate a wind erosion balance of $6.5 \mathrm{t} \mathrm{ha}^{-1}$, as a result of multiplying both values. Variations in random roughness are conditioned by the loss and deposited material balance in the plot. The wind erosion terrain modifies its micro-topog-

Table 3. Average bulk density (ABD) in soils, height loss detected by the laser-scanner and resulting wind erosion by this method and from traps $(\mathrm{n}=5)$

\begin{tabular}{|c|c|c|c|c|c|c|c|}
\hline \multirow{3}{*}{$\begin{array}{l}\text { Soil } \\
\text { type }\end{array}$} & \multirow{3}{*}{$\begin{array}{l}\mathrm{ABD} \\
\left(\mathrm{t} \mathrm{m}^{-3}\right)\end{array}$} & \multicolumn{3}{|c|}{ Crusted soil } & \multicolumn{3}{|c|}{ Tilled soil } \\
\hline & & \multirow{2}{*}{$\begin{array}{l}\text { Height loss } \\
\text { (mm) }\end{array}$} & \multicolumn{2}{|c|}{ Wind erosion $\left(\mathrm{t} \mathrm{ha}^{-1}\right)$} & \multirow{2}{*}{$\begin{array}{l}\text { Height loss } \\
\text { (mm) }\end{array}$} & \multicolumn{2}{|c|}{ Wind erosion $\left(\mathrm{t} \mathrm{ha}^{-1}\right)$} \\
\hline & & & $\begin{array}{c}\text { Laser-scanner } \\
\text { method }\end{array}$ & Traps & & $\begin{array}{c}\text { Laser-scanner } \\
\text { method }\end{array}$ & Traps \\
\hline AR & 1.26 & $0.26 \pm 0.08$ & $3.3 \pm 0.1$ & $2.8 \pm 0.2$ & - & - & - \\
\hline AT & 1.28 & $0.51 \pm 0.09$ & $6.5 \pm 1.2$ & $5.9 \pm 0.8$ & $0.97 \pm 0.18$ & $12.4 \pm 2.3$ & $11.7 \pm 1.8$ \\
\hline $\mathrm{CL}$ & 1.41 & $0.14 \pm 0.03$ & $2.0 \pm 0.4$ & $1.7 \pm 0.3$ & - & - & - \\
\hline $\mathrm{CM}$ & 1.31 & $0.24 \pm 0.11$ & $3.2 \pm 1.4$ & $2.9 \pm 1.1$ & $0.78 \pm 0.14$ & $10.2 \pm 1.8$ & $9.2 \pm 1.3$ \\
\hline FL & 1.29 & $0.18 \pm 0.07$ & $2.3 \pm 0.9$ & $1.9 \pm 0.7$ & $0.71 \pm 0.21$ & $9.2 \pm 2.7$ & $8.0 \pm 2.0$ \\
\hline LP & 1.36 & $0.78 \pm 0.15$ & $10.6 \pm 2.0$ & $9.4 \pm 1.6$ & - & - & - \\
\hline
\end{tabular}

Explanations as in Table 1. 

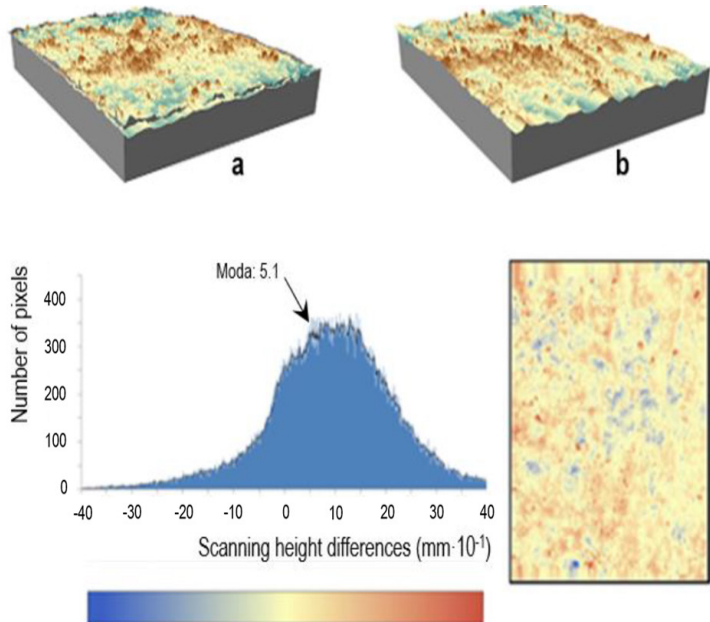

Fig. 2. Digital terrain models: $a$ - before and $b$ - after blowing extra wind with the tunnel fan; and erosion maps of a sample from a tilled Anthrosol plot.

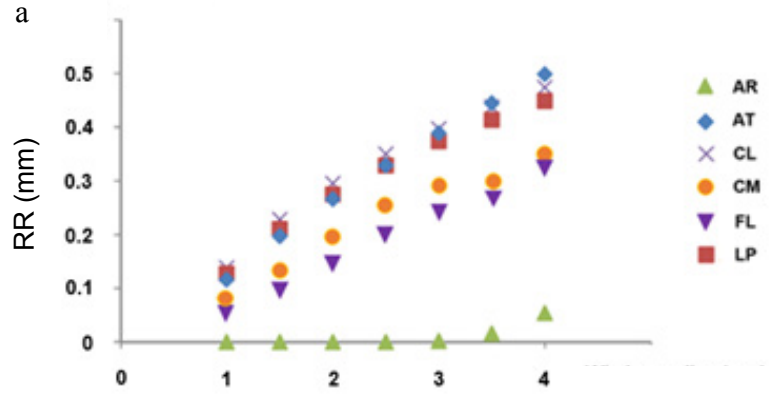

b

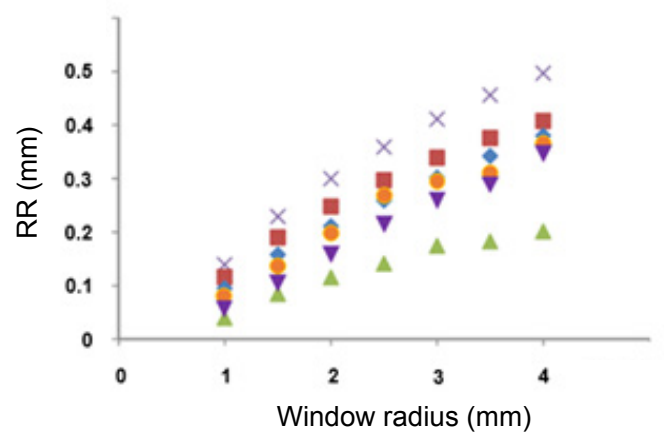

Fig. 3. Roughness of the six soil types at different spatial scales (from 1 to $4 \mathrm{~mm}$ ), a - before and b-after simulation.

raphy, which in turn is likely to act on its erosive action in future wind events (Ravi et al., 2011). However, this effect depends on the study scale and does not follow any clear pattern, as observed in Fig. 3. Figure 4 shows how erosion decreased roughness in AT and LP plots, which was progressively augmented in larger window sizes. CL, CM, FL and AR plots, on the contrary, became rougher, especially with larger window sizes, except AR where the trend reversed after the $3 \mathrm{~mm}$ window.

These results highlight the importance of obstacles to wind erosion, which increases the soil surface resistance to wind and slows down the drag of particles, retaining

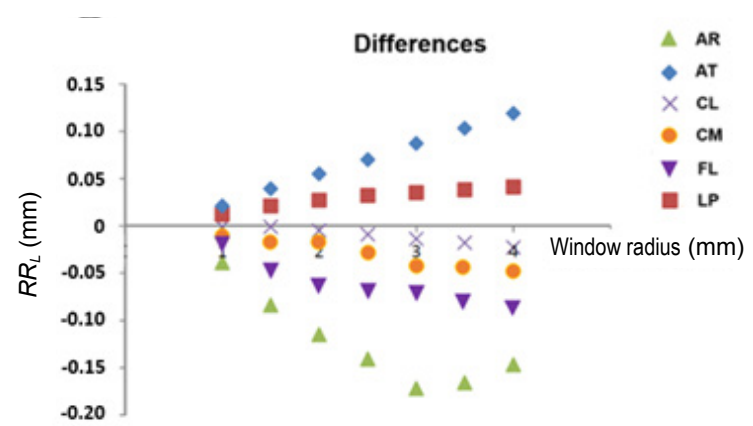

Fig. 4. Random roughness of the six soil types at different spatial scales: $R R_{L}$ from 1 to $4 \mathrm{~mm}$.

them and increasing surface roughness. The different behaviour of the CL, CM, FL and AR plots with respect to random roughness is due to higher stone content and/ or remnant vegetation being highly resistant to the wind, and the increasing surface roughness. In AT and LP plots, on the contrary, initial roughness is due to the presence of large unstable wind-eroded aggregates, which result in a decreased surface roughness.

\section{CONCLUSIONS}

1. We analyzed analyzed the possibility of using a lowcost laser scanner to evaluate the variation in soil surface micro-topography due to wind, finding that it enables soil wind erosion to be quantified both quickly and accurately. However, the micro-topography modification by wind erosion depends on the study scale.

2. Aggregation of $\mathrm{CaCO}_{3}$ in the wind-erodible fraction in Calcisols and high surface stoniness caused the lowest wind erosion. On the contrary, Leptosols provided the lowest protection against the direct impact of wind. Arenosols is a special case, as protective vegetation and low content in very fine sand and coarse silt (the fractions most susceptible to wind erosion) exhibited only a minor loss of material.

3. We observed that tilled AT are more eroded and generate higher amounts of dust than Cambisols and Fluvisol, mainly due to the effect on soil crusting of an intensive horticultural crop, while Cambisols are in low-tilled cereal fields and Fluvisol are tilled soil under ecological citrus trees.

4. There is an interaction between the erosive action of wind and soil surface, which depends on the soil surface stone content, remnant vegetation and the presence of unstable wind-eroded aggregates.

Conflict of interest: The Authors do not declare conflict of interest.

\section{ACKNOWLEDGMENTS}

The authors are grateful to Deborah Fuldauer for the English language revision. 


\section{REFERENCES}

Aguilar M.A., Aguilar F., and Negreiros J., 2009. Off-the-shelf scanning and close-range digital photogrammetry for measuring agricultural soils microrelief. Biosystem Engineering, 103(4): 504-517, https://doi.org/10.1016/j.biosystemseng. 2009.02.010

Asensio C., Lozano F.J., Ortega E. and Kikvidze Z., 2015. Study on the effectiveness of an agricultural technique based on aeolian deposition, in a semiarid environment. Environmental Engineering and Management J., 14(5): 1143-1150, https://doi.org/10.30638/eemj.2015.125

Asensio C., Lozano F.J., Gallardo P. and Giménez A., 2016. Soil wind erosion in ecological olive trees in the Tabernas desert (Southeastern Spain): a wind tunnel experiment. Solid Earth, 7: 1233-1242, https://doi.org/10.5194/se-71233-2016

Belnap J., 2003. Biological soil crusts and wind erosion. In Biological Soil Crusts: Structure, Function, and Management (Eds J. Belnap, O.L. Lange). Berlin, Springer Verlag, 339-347, https://doi.org/10.1007/978-3-642-56475-8

Beniston J.W., Shipitalo M.J., Lal R., Dayton E.A., Hopkins D.W., Jones F., Joynes A. and Dungait J.A.J., 2015. Carbon and macronutrient losses during accelerated erosion under different tillage and residue management. European J. Soil Sci., 66(1), 218-225, https://doi.org/10.1111/ejss.12205

Benlhabib O., Yazar A., Qadir M., Lourenço E. and Jacobsen S.E., 2014. How Can We Improve Mediterranean Cropping Systems? J. Agronomy Crop Sci., 200(5): 325-332, https:// doi.org/10.1111/jac.12066

Borrelli P., Panagos P., Ballabio C., Lugato E., Weynantgs M. and Montanarella L., 2016. Towards a Pan-European assessment of land susceptibility to wind erosion. Land Degradation Development, 27(4): 1093-1105, https://doi. org/10.1002/ldr.2318

Cantón Y., Solé A., Asensio C., Chamizo S. and Puigdefábregas J., 2009. Aggregate stability in range sandy loam soils relationships with runoff and erosion. Catena, 77(3), 192-199, https://doi.org/10.1016/j.catena.2008.12.011

Cantón Y., Solé A., De Vente J., Boix-Fayos C., Calvo A., Asensio C. and Puigdefábregas J., 2011. A review of runoff generation and soil erosion across scales in semiarid South-eastern Spain. J. Arid Environ., 75(12), 1254-1261, https://doi.org/10.1016/j.jaridenv.2011.03.004

Colazo J.C. and Buschiazzo D.E., 2010. Soil dry aggregate stability and wind erodible fraction in a semiarid environment of Argentina. Geoderma, 159: 228-236, https://doi. org/10.1016/j.geoderma.2010.07.016

Colazo J.C. and Buschiazzo D.E., 2015. The Impact of Agriculture on Soil Texture Due to Wind Erosion. Land Degradation Development, 26(1): 62-70, https://doi. org/10.1002/ldr.2297

Fister W. and Ries J.B., 2009. Wind erosion in the central Ebro Basin under changing land use management. Field experiments with a portable wind tunnel. J. Arid Environ., 73: 996-1004, https://doi.org/10.1016/j.jaridenv.2009.05.006

Hagen L.J., Van Pelt S. and Sharratt B., 2010. Estimating the saltation and suspension components from field wind erosion. Aeolian Res., 1: 147-153, https://doi.org/10.1016/j. aeolia.2009.08.002
Le Bissonnais Y., Montier C., Jamagne M., Daroussin J. and King D., 2002. Mapping erosion risk for cultivated soil in France. Catena, 46: 207-220, https://doi.org/10.1016/ S0341-8162(01)00167-9

Leenders J.K., Sterk G. and van Boxel J.H., 2011. Modelling wind-blown sediment transport around single vegetation elements. Earth Surface Processes and Landforms, 36(9): 1218-1229, https://doi.org/10.1002/esp.2147

Lozano F.J., Soriano M., Martínez S. and Asensio C., 2013. The influence of blowing soil trapped by shrubs on fertility in Tabernas district (SE Spain). Land Degradation Development, 24: 575-581, https://doi.org/10.1002/ldr.2186

Novara A., Gristina L., Saladino S.S., Santoro A. and Cerdà A., 2011. Soil erosion assessment on tillage and alternative soil managements in a Sicilian vineyard. Soil Till. Res., 117: 140-147, https://doi.org/10.1016/j.still.2011.09.007

Ravi S., D’Odorico P., Breshears D.D., Field J.P., Goudie A.S., Huxman T.E., Li J., Okin G.S., Swap R.J., Thomas A.D., Van Pelt S., Whicker J.J. and Zobeck T.M., 2011. Aeolian processes and Biosphere. Reviews of Geophysics, 49: 1-45, https://doi.org/10.1029/2010RG000328

Rawlins B.G., Turner G., Wragg J., McLachlan P. and Lark R.M., 2015. An improved method for measurement of soil aggregate stability using laser granulometry applied at regional scale. European J. Soil Sci., 66(3): 604-614, https://doi.org/10.1111/ejss.12250

Rodríguez-Caballero E., Cantón Y., Chamizo S., Afana A. and Solé-Benet A., 2012. Effects of biological soil crusts on surface roughness and implications for runoff and erosion. Geomorphology, 145: 81-89, https://doi.org/10.1016/j. geomorph.2011.12.042

Toure A.A., Rajot J.L., Garba Z., Marticorena B., Petit C. and Sebag D., 2011. Impact of very low crop residues cover on wind erosion in the Sahel. Catena, 85 (3): 205-214, https:// doi.org/10.1016/j.catena.2011.01.002

Udo K. and Takewaka S., 2007. Experimental study of blown sand in a vegetated area. J. Coastal Res., 23(5): 1175-1182, https://doi.org/10.2112/05-0499.1

Weber J., Kocowicz A., Debicka M. and Jamroz E., 2017. Changes in soil morphology of Podzols affected by alkaline fly ash blown out from the dumping site of an electric power plant. J. Soils Sediments, 17: 1852-1861. https://doi. org/10.1007/s11368-016-1599-7

Youssef F., Visser S.M., Karssenberg D., Erpul G., Cornelis W.M., Gabriels D. and Poortinga A., 2012. The effect of vegetation patterns on wind-blown mass transport at the regional scale: A wind tunnel experiment. Geomorphology, 159: 178188, https://doi.org/10.1016/j.geomorph.2012.03.023

Zhao H.L., He Y.H., Zhou R.L., Su Y.Z., Li Y.Q., and Drake S., 2009. Effects of desertification on soil organic $\mathrm{C}$ and $\mathrm{N}$ content in sandy farmland and grassland of Inner Mongolia. Catena, 77: 187-191, https://doi.org/10.1016/j.catena.2008.12.007

Zobeck T.M., Baddock M., Van Pelt R.S., Tatarko J., and Acosta-Martínez V., 2013. Soil property effects on wind erosion of organic soils. Aeolian Res., 10: 43-51. https://doi.org/10.1016/j.aeolia.2012.10.005 